\title{
EDITORIAL
}

\section{Pasando el testigo de la Revista.}

\section{Óscar Martínez Azumendi y Nekane Sagasti Legarda}

Para cuando este número de la Revista esté en la calle, el XXVI Congreso Nacional de la AEN ya habrá tenido lugar en Valencia, y en él se habrá proclamado una nueva Junta de Gobierno incluido un nuevo Director de Publicaciones quien, junto a su propio Consejo de Redacción, continuará a partir de ahora la tarea editorial de la Revista. Por nuestra parte, como parte del equipo saliente, también es la ocasión propicia para hacer una reflexión acerca de lo conseguido y aquello otro que no fue posible. Pero antes, con carácter general y previo al resto de consideraciones que siguen, merece la pena reseñar que la política editorial, de tanto la Revista como las otras publicaciones AEN, ha sido claramente continuista con la línea marcada durante la junta directiva previa, al habernos mantenido con la proclamada en el Congreso de Canarias en junio de 2012 el mismo Director y Secretaria de Redacción del anterior periodo y renovarse parcialmente el resto del Consejo de Redacción, lo que permitió un fácil tránsito editorial y el afianzamiento de algunos cambios ya introducidos previamente.

Es así que estos últimos tres años han sido un periodo de consolidación y mejora de algunos objetivos planteados durante el trienio anterior, tales como la recuperación de la frecuencia trimestral, la impresión y distribución de los números en las fechas estrictamente programadas, o la adaptación y actualización de las normas de presentación de los manuscritos adaptándolos a los requerimientos internacionales de índices y repositorios bibliográficos en los que hemos ido aumentando nuestra presencia progresivamente, si bien todavía para alguno de ellos seguimos pendientes de conseguir la inclusión. En este sentido, el tema de los anteriores requisitos formales exigidos por algunos índices, así como la pertinencia o no de la búsqueda de otros objetivos bibliométricos, no han dejado de ser objeto de debate mantenido a lo largo de todos estos años, habiendo sido nuestra política editorial el adherirnos dentro de lo posible a sus imperativos, en el convencimiento de que ello redundaría en una mayor calidad formal, prestigio y visibilidad de la publicación y con ella de la propia AEN, aun conscientes de algunas servidumbres que este objetivo pudieran implicar y que no resultaran tan del agrado para algún socio.

En cualquier caso, garantizar, por otra parte, la calidad de los contenidos ha sido la principal tarea del Comité Editorial y del amplio equipo de colegas que de forma desinteresada ha contribuido a la revisión ciega de los trabajos enviados, todos ellos sometidos a la consideración de al menos dos lectores junto a un ter- 
cer revisor de aspectos formales. Revisores cuyos nombres han pasado a incluirse anualmente en las páginas de la Revista como reconocimiento a su trabajo y de los que esta estará siempre necesitada como seguro de excelencia.

En relación con la cantidad y diversidad del material recibido para su publicación, en todo este tiempo se ha consolidado el número de trabajos sometidos a consideración, incluido cierto aumento en el número de envíos desde el extranjero, especialmente Latinoamérica, así como ha aumentado de alguna forma su calidad, no temiéndose en este momento por una eventual carestía en los mismos. Es precisamente la relativa abundancia de trabajos, lo que llevó a limitar la extensión de los mismos, posibilitando de esta forma el mayor número de artículos publicados.

Siendo la Revista el órgano público de la AEN - Profesionales de la Salud Mental, no es de extrañar que un tema de debate interno entre los socios sea el tipo y orientación teórica predominante en los trabajos publicados, habiendo quien pudiera considerar que algún tipo de texto pudiera verse discriminado a favor de otros más fácilmente encajables en los requisitos formales exigidos para la publicación de trabajos originales. Si bien esto pudiera haber ocurrido en algún caso extremo de desviación formal manifiesta, en la práctica los trabajos publicados o rechazados lo han sido independientemente de la adscripción teórica de los mismos, si no que lo fueron por decisión de los lectores elegidos precisamente en base a su dominio del área estudiada. Más aún, para algunos otros trabajos de interés editorial se han hecho también todos los esfuerzos para aconsejar y ayudar a sus autores a adaptar el manuscrito a los requerimientos exigibles para ser considerados como trabajos originales indexables, o si bien tenían claramente otro carácter se han publicado en apartados tales como las secciones de Para el Debate, Informes, Márgenes de la Psiquiatría o las recuperadas Páginas de la Asociación, lo que ha permitido garantizar la presencia de artículos de opinión codo con codo a los incluidos en las secciones de originales y revisiones con mayor exigencia formal en su presentación y evaluación.

Hemos buscado igualmente una mayor ligereza editorial dentro de lo posible, tanto estética incluyendo de forma modesta imágenes acompañantes a algunos trabajos, así como de contenidos al incluir temas más livianos o secciones más o menos fijas, como el Boticarium o las Reflexiones Nerviosas, redactadas en un tono más informal pero no por eso menos sólido. Por otra parte, se ha iniciado de forma todavía limitada la inclusión de materiales elaborados por personas afectadas por una enfermedad mental o sus familiares, siendo este un aspecto sin duda del mayor interés futuro.

La Revista ha sabido también seguir adaptándose al ritmo de los tiempos, ampliando y consolidando su versión digital, para la que se dispone ahora de su propio EISSN digital diferenciado. Publicada en Internet en una plataforma OJS con dominio propio y diferenciado del corporativo de la Asociación (www.revistaaen.es), sus contenidos están disponibles de forma universal y gratuita adscribiéndose todos 
EDITORIAL

ellos bajo una "Licencia Creative Commons" de libre distribución, a la vez que cada trabajo es marcado individualmente para su fácil localización e indexación por los buscadores automatizados. Aun así, durante todo este tiempo, nos hemos resistido a dar el salto a la edición exclusivamente digital que supusiera el abandono del formato en papel, valorando lo que la llegada regular de la Revista al domicilio de cada socio pudiera representar como recordatorio tangible físicamente de nuestra pertenencia a la AEN. Queda para más adelante cualquier otra reconsideración.

Por último, no podemos terminar sin agradecer a los autores su confianza en la Revista y a quienes desde aquí pedimos disculpas si ocasionalmente no les hemos podido responder con la agilidad merecida debido a nuestras propias limitaciones de disponibilidad. Agradecimiento también extensible al resto del Consejo de Redacción y lectores anónimos por su desinteresada participación en la valoración de los trabajos recibidos. De igual manera que deseamos todo lo mejor al siguiente equipo editorial para los próximos tres años, dejando en sus manos y a partir de ahora la apasionante tarea de seguir mejorando el alcance y prestigio de la Revista AEN y la Asociación que la sostiene. Estamos convencidos de que así será. 